https://jurnal.unigal.ac.id/index.php/jall/index

ISSN: 2598-8530

September 2017, Vol. 1 No. 2

English Education Program

Faculty of Teacher Training and Education

Galuh University

\begin{tabular}{|ccc|}
\hline Received: & Accepted: & Published: \\
\hline July 2017 & August 2017 & September 2017 \\
\hline
\end{tabular}

\title{
AN ANALYSIS OF FILLERS USED BY LECTURER AND STUDENTS IN EFL CLASSROOM INTERACTION
}

\author{
Gotin Siti Fatimah \\ gotinfatimah@gmail.com \\ SD IT Mutiara Umat Majenang - Cilacap \\ Bunga Febriani \\ bunga.febriani@gmail.com \\ English Education Program, Galuh University-Ciamis \\ Rita Apollonia \\ English Education Program, Galuh University-Ciamis
}

\begin{abstract}
This paper reports on fillers used by lecturer and students in EFL Classroom Interaction. Therefore, the study was aimed to investigate the types and frequency of the lecturer and the students' fillers and the functions of fillers in EFL Classroom Interaction. To gain the data, the writer employed a qualitative case study and the data were obtained through the observation. Then, the data from the observations were analyzed by transcribing the whole of the utterances that contained fillers to find out the types, frequency and functions of fillers. The writer described the data of the observation qualitatively. In the present study, the writer proposed two research questions: (1) Which types of lexicalized and unlexicalized fillers will be used and how often do the lecturer and the students use both fillers in EFL Classroom Interaction? (2) What are the functions of lexicalized and unlexicalized fillers used by the lecturer and the students in EFL Classroom Interaction? In responding to the first research questions, the writer found that the lecturer and the students used filler in their utterances, the fillers found were both lexicalized and unlexicalized fillers. The lecturer used 504 fillers, while the students used 65 fillers. Furthermore, the result of second research question also found. The highest percentage of the fillers' function of the lecturer and the students reached the same range used as a mark hesitation : $(28.91 \%)$ for the lecturer and $(77.5 \%)$ for the students.
\end{abstract}

Keywords: Discourse Markers, Fillers, Classroom Interaction 


\section{INTRODUCTION}

Fillers and other phenomenon of spoken interaction such as have been dealt with in discourse analysis, a primarily with branch of linguistics study examining the use of language by its native population whose major concern in investigating language function along with its forms, produced both orally and in writing. Moreover, identification of linguistics qualities of various genres, vital to their recognition and interpretation, together with cultural and social aspecs that support its comprehension, is the domain of discourse analysis.

In spoken interaction, people often produce or say "ee"..., "err"...,"ehm"..., or "well", "you know", "I mean", "kind of", and other similar expressions. According to Baalen( 2001, p. 7), these kinds of utterances are called fillers. He defined fillers as sounds or words or phrases they can appear anywhere in the utterance and that can be deleted from the utterance without a change in conten On the other simple words, Yule (2006, p. 242) identified fillers as a break in the flow of speech.

Previously, there are some researchers who have conducted their studies related to the present topic. Those previous studies are dealing with the use of fillers, yet they are in the different field. The first previous study is from Erten (2013) who emphasizes a study about the importance of teaching fillers to students of ESL/EFL classroom in International Journal of Teaching and Education of Turkey. The second study is from Santos, Alarcon and Pablo and Hubackova (2015) who present about the finding that focus on teaching fillers in FL classrooms of different teaching context and various FL classes in Article Journal of Mexico. Finally, Navratilova (2015) carries out a study at find out types and function of fillers used by malee and female students of the English Education Program in Argumentative Talks in Journal of Linguistics and Language Teaching of Indonesian.

Despite all those previous studies, the writer is interested in exploring the fillers are used by lecturers and students in EFL classroom interaction. Henceforth, considering to endure the previous studies, the writer conducts this study in different point of view related to the fillers in discourse marker field. However, the analysis of this certain topic is highlighted to the types of lexicalized and unlexicalized filers are used by lecturer and students in classroom interaction and functions of lexicalized and unlexicaized fillers used by lecturer and students.

The present study is also supported by its literature review as its theoritical foundation. The review of related literature deals with discourse markers, fillers and classroom interaction.

\section{Discourse Markers}

The first theory used by the writer is Discourse Marker. The study of Discourse markers are rooted in discourse analysis. It popularities has increased within the last two decades. A lot of studies have been conducted to see whether discourse markers contribute to pragmatics and communicative competence, and if they do, in what ways. In fact, the popularity of the topic to do research on discourse markers has even created fuzziness in terminology (Aşik, 2012, p. 16), discourse markers are words and phrases used to mark boundaries in conversation between topic and the next. Carter and McCarthy, (1997, p.13) they could be words or phrases such as "right", "OK", " I see", "I mean", "you know", "like", etc, and help the speakes in a conversation negotiate their way of thinking. 


\section{Fillers}

According to Stenström (1994, p. 222), filler is lexically empty item with uncertain discourse functions, except to fill a conversational gap. It means that fillers commonly occur to mark hesitation or to hold control of a conversation, while the speaker thinks what to say next. In Indonesian, fillers are called "Jeda terisi". Kridalaksana (1993, p. 88) defines "Jeda Terisi" as "Keragu-raguan dalam wacana spontan yang diisi sebagian atau seluruhnya oleh bunyi/ ungkapan seperti "e", "apa itu”, dan sebagainya" (The hesitation in the spontaneous speech that is filled partly or fully by the sounds or expressions, such as "e", "apa itu", etc). Moreover, fillers can be said to reflect how the speakers structure a message, where they hesitate, wherethey prepare semantic-syntactic chunk, and where they manage to breathe. As Stenström (1994) stated, "pauses can be said to mark off performance unit, ie the strings of words that we manage to process in one go" (p.7). Fillers also describe discourse markers speakers use when they think and/or hesitate during their speech.

\section{Classroom Interaction}

According to Richards, Platt \& Platt, (1992), Classroom interaction as the patterns of verbal and non-verbal communication and the types of social relationships which occur within classrooms. The study of classroom interaction may be a part of studies of Classroom Discourse, Teacher Talk and Second Language Acquisition. Studies of the classroom, both primary and secondary, have shown that the language used by the teacher affects the language produced by the learners, the interaction generated and hence the kind of learning that takes place. Classroom language and interaction are even more important because language is the subject of study as well as the medium for learning. When students listen to the teacher's instructions and explanations, when they express their views, answer questions and carry out tasks and activities, they are not only learning about the language but also putting to use the language that they are learning.

\section{METHOD}

In the study, the writer applied qualitative research design. Case study is also designed to bring out the details from the view point of the participants by using multiple sources of data. According to Creswell (2014, p. 43) case studies are a design of inquiry found in many fields, especially evaluation, in which the researcher develops an in-depth analysis of a case, often a program, event, activity, process, or one or more individuals. In this study, the writer took one lecturer who was teaching Reading for Specific Purposes course in EFL classroom on English department at a private college in Ciamis. Meanwhile for the student's participants there were 22 students which consist of 9 male and 13 female students inside at the first semester of the 2017-2018 education years.

In collecting the data, the writer used non-participant observation technique. In a non-participant observation study, the writer was not a participant in the activity observed but, rather "sit on the sidelines" and watch; they are not directly involved in the situation they are observing (Fraenkel, Wallen, \& Hyun, 2012, p. 446). Then, to collect the data the study used observation as the instrument. According to Creswell (2014, p. 239), a qualitative observation is when the researcher takes field notes on the behavior and activities of individuals at the research site. In these field notes, the researcher records, in 
an unstructured or semistructured way (using some prior questions that the inquirer wants to know), activities at the research site.

For performing the analysis and finding the answers of the research questions, the writer might use these following steps : to identify Lexicalized and Unlexicalized fillers used by the lecturer and the students the writer grouped the fillers based on the theory about the types of fillers from Rose (1998), that is, unlexicalized (UF) and lexicalized (LF). In analyzing the data, the writer also provided a translation of the fillers from Indonesian to English. The writer made two tables in order to differentiate the data of fillers production from the lecturer and the students. Then, the writer counted the number of fillers in each type of fillers.

\section{FINDINGS AND DISCUSSIONS}

This section discusses the data finding from classroom observation. Each phase of discussion is devoted to discover the answer to the research questions.

\section{Types of Lexicalized and Unlexicalized Fillers Used by The Lecturer and The Students in EFL Classroom Interaction}

The writer found many fillers used by the lecturer and students in the classroom interaction. It was found some utterances that contained Lexicalized and Unlexicalized fillers during the process of teaching and learning in the EFL classroom interaction on the Reading for Specific Purposes course. Therefore, the details of finding about the types and the frequency of fillers occurrences could be seen in Table 1.

\section{Table 1: Frequency of Lexicalized and Unlexicalized fillers used by the lecturer and the students}

\begin{tabular}{lcccc}
\hline Participants & \multicolumn{5}{c}{ Frequency of Occurrances } \\
\cline { 2 - 5 } & $\mathrm{N}$ & $(\mathrm{LF})$ & $\mathrm{N}$ & $\%$ \\
Lecturer & 460 & $96.84 \%$ & 44 & $46.80 \%$ \\
Students & 15 & $3.15 \%$ & 50 & $53.19 \%$ \\
TOTAL & 475 & $99.99 \%$ & 94 & $99.99 \%$ \\
\hline
\end{tabular}

From the table above, it could be seen that the lecturer mostly used Lexicalized Fillers while she was doing an interaction in the classroom. It was clearly shown that $96.84 \%$ or 460 fillers were used by the lecturer in the classroom interaction. Meanwhile the students mostly used Unlexicalized Fillers as shown on the table above that $53.19 \%$ or 50 fillers were used by the students.

Furthermore, the percentage of each type of fillers can be seen in the following table 2 below. It would be explained each type of the lexicalized and unlexicalized fillers in the utterances of the lecturer when did interaction with the students.

Table 2:Types of fillers and its frequency produced by the lecturer

\begin{tabular}{lccc}
\hline Types of Fillers & Fillers & \multicolumn{2}{c}{ Frequency } \\
\cline { 3 - 4 } & & $\mathrm{N}$ & $\%$ \\
Lexicalized & $\mathrm{Ok}$ & 394 & $76.20 \%$ \\
\hline
\end{tabular}




\begin{tabular}{lccc}
\hline & Yes & 28 & $6.11 \%$ \\
& Ya & 30 & $6.55 \%$ \\
& Yah & 6 & $1.31 \%$ \\
& Actually & 24 & $5.24 \%$ \\
& Well & 4 & $0.87 \%$ \\
& Right & 14 & $3.05 \%$ \\
& Like & 1 & $0.26 \%$ \\
Unlexicalized & What is it & 4 & $0.87 \%$ \\
& Ee & 41 & $93.18 \%$ \\
& Ehm & 3 & $6.81 \%$ \\
\hline
\end{tabular}

The percentage of each type of fillers can be seen in Table 2. The following parts would explain each type of the lexicalized fillers in the utterances of the students when did interaction in the classroom.

Table 3: Types of Lexicalized and Unlexicalized fillers and its frequency produced by the students

\begin{tabular}{lccc}
\hline Types of Fillers & Fillers & \multicolumn{2}{c}{ Frequency } \\
\cline { 3 - 4 } Lexicalized & & $\mathrm{N}$ & $\%$ \\
& Yes & 10 & $15.38 \%$ \\
& Ya & 2 & $3.07 \%$ \\
& Yah & 1 & $1.53 \%$ \\
& Right & 1 & $1.53 \%$ \\
Unlexicalized & Like & 1 & $1.53 \%$ \\
& Ee & 41 & $63.07 \%$ \\
& Ehm & 9 & $13.84 \%$ \\
\hline
\end{tabular}

There were several similarities between the types of fillers used by the lecturer and the students Firstly, both of them produced the Lexicalized fillers [ya], [yes], [yah],[right],[like], although the frequencies of using those fillers were dominant produced by the first lecturer. Also, both the lecturer and the students produced the Unlexicalized fillers [ee],and [ehm]. Secondly, the lecturer produced more lexicalized fillers than the unlexicalized fillers, while the students produced more unlexialized fillers than the lexicalized one.

The Function of Lexicalized and Unlexicalized fillers used by the lecturer and the students in EFL Classroom Interaction

In this research, the writer summarized five functions of the fillers in the spoken interaction mainly based on the theories of Stenström (1994), those are, fillers function as a hold to the turn, as a mark of hesitation, empathizers, time-creating devices, and editing term. In the production of fillers by the lecturer, it was shown that all those functions of fillers were used, but they were different in proportion. The lecturer tended to produce more fillers as mark of hesitation $(28.91 \%)$. That percentage of the fillers was followed by fillers as empathizers $(25.30 \%)$, fillers as time-creating devices $(24.9 \%)$, and fillers that functioned for holding the turn (14.45\%). The least percentage on the function of fillers produced by the lecturer was fillers as an editing term $(7.22 \%)$. The types of fillers produced by the students also had several functions. In this part, the writer would like to 
analyze each type of the fillers occurred in the conversation of the students and define its function/s. In the transcribing data of the lecturer and students on the part of students' conversation, the writer found that the fillers could be defined in five functions based on the Stenström's (1994) theory about the functions of fillers. Similar with the lecturers' one, the highest percentage on the functions of fillers produced by the students was as a mark of hesitation $(77.5 \%)$. While the second highest percentage of the fillers produced by the lecturer functioned as empathizers (15\%), it was functioned as time-creating devices (5\%) in the students'. Then, the number was followed by fillers functioned to hold the turn $(2.5 \%)$, and fillers functioned as an editing term $(2.5 \%)$.

The findings above are based on the problems statement that are presented by the writer. The analysis of fillers was conducted to find out the purposes of this study that is to investigate the types of Lexicalized and Unlexicalized fillers and its frequency and to find out the function of Lexicalized and Unlexicalized fillers used by the lecturer and the students in the classroom interaction. From the findings, the writer infers several points. First of all, it could be seen that based on the first research question, the writer found that both of types fillers were used by the lecturer and the students. It was Lexicalized and Unlexicalized fillers. Moreover, most of the types of fillers produced by the lecturer and the students were almost similar .

Secondly, to answer the first research question, the writer analyzed the types of fillers used by the lecturer and the students by transcribing the whole of the conversations when they did the interaction in the classroom. The result showed there were 569 fillers found from the 368 utterances in the conversation among the lecturer and the students. A number of fillers found in the lecturer's utterance were 504 fillers which consisted of 460 for lexicalized fillers and 44 for unlexialized fillers. Meanwhile, in the students' utterances were also found 65 fillers, which consist of 15 for lexicalized fillers and 50 for unlexicalized fillers.

Thirdly, to answer the second research question, the writer analyzed the function of fillers used by the lecturer and the students in the classroom interaction. From the analysis had been found, the result showed that there were five functions of fillers based on the theory of Stenstrom (1994), such as fillers used to hold the turn, fillers used as a mark hesitation, fillers used as empathizers,fillers used as time-creating devices and fillers used as editing term. The highest percentage of the fillers' function used by the lecturer was fillers as a mark hesitation (28.91\%), followed by fillers asfillers as empathizers $(25.30 \%)$, fillers as time-creating devices $(24.9 \%)$, and fillers that functioned for holding the turn $(14.45 \%)$, the least percentage on the function of fillers was fillers as an editing term $(7.22 \%)$. Meanwhile, for the students found $(77.5 \%)$ fillers used as a mark of hesitation as the highest percentage, fillers was functioned as empathizers $(15 \%)$, then followed by fillers functioned as time-creating devices $(5 \%)$, fillers functioned to hold the turn $(2.5 \%)$, and fillers functioned as an editing term (2.5\%).

The result of this study has difference with the previous study. Some previous studies had analyzed about fillers, however the writer tried to analyze with the different purposes in identifying the data with previous studies. The first previous study which conducted by Erten (2013) entitled "Teaching Fillers and Student's filler usage : A Study Conducted at ESOGU Preparation School", the second previous study bySantos, Alarcon and Pablo and Hubackova (2015). They designed a research entitled "Fillers and the Development of Oral Strategic Competence in Foreign Language Learning", and the last previous study by Navratilova (2015) entitled "Fillers Used by Male and Female Students of English Education Study Program in Argumentative talks". From those previous studies, they have not taken the detail description of types of fillers used and explained the 
function of fillers in depth. Thus, in this present study, the writer analyzed and explored more detail about the types and the function of Lexicalized and Unlexicalized fillers used by the lecturer and the students in the classroom interaction basen on the theory of Rose (1998) and Stenstrom (1994).

\section{CONCLUSIONS AND SUGGESSTIONS}

In conclusion, this study investigated the types of Lexicalized and Unlexicalized fillers and the function of Lexicalized and Unlexicalized fillers used by the lecturer and the students in EFL classroom interaction. There was found that both of types fillers were used by the lecturer and the students in classroom interaction.

In responding to the first research questions, the writer found that the lecturer used filler in her utterances, the fillers found based on the theory from Rose (1998) were Lexicalized and Unlexicalized fillers, also it was found in the students utterances. The lecturer used 504 fillers in her utterances, while the students used 65 fillers in their utterances. However,there were differences among the lecturer and the students, the lecturer mostly used Lexicalized fillers than Unlexicalized one, while the students used mostly the Unlexicalized one

Furthermore, the result of second research question also found. The writer used the theory on the functions of fillers from Stenstrom (1994), such as fillers used to hold the turn, fillers used as a mark hesitation, fillers used as empathizers, fillers used as timecreating devices and fillers used as editing term. The highest percentage of the fillers' function of the lecturer and the students were same that was fillers used as a mark hesitation $(28.91 \%)$ for the lecturer and (77.5). Meanwhile the lowest percentage of the fillers' found fillers as an editing term (7.22) for the lecturer and (2.5) for the students. The whole of the results had answered both of the research questions.

However, this study has an obvious limitations. The writer did not investigate or find out the reasons why the lecturer and the students use fillers in their utterance in classroom interaction. Whereas, the investigation would be helpful for the writer to know the lecturer's and the students' reasons in the use of fillers when they are doing the interactin in the classroom. based on the limitations of the presents research that did not investigate the lecturer's and the students' reasons of using fillers in the classroom interaction. Besides, the study was only concerned within the scope of college. Thus, the writer expect that it is necessary to conduct the study for further researchers in other level of education in order to gain the more specific result relating to the reason of using fillers.

\section{REFERENCES}

Aşik, A.( 2012). Discourse marker and spoken English : Nonnative use in the Turkey EFL setting. PhD Dissertation, Gazi University, Ankara Turkey. Retrieved on November $23^{\text {rd }}, 2016$ from : http//www.iises.net/download/Soubory/.../pp67-79_ijoteV2N3.pdf

Baalen, I., V. (2001). Male and female language: Growing together? Historical Sociolinguistics and Sociohistorical Linguistics journal, Retrieved on November $25^{\text {th }}, 2016$, from : http://www.let.leidenuniv.nl/hslshl /vanBaalen.htm. 
Brinton, L., J.(1996). Pragmatic marker in English : Grammaticalization and discourse functions. Retrieved on November 23 ${ }^{\text {rd }}$, 2016 from : http//www.iises.net/download/Soubory/.../pp67-79_ijoteV2N3.pdf

Brown, H. (2001). Teaching by principle an interactive approach to language pedagogy, Retrieved on December $1^{\text {st }}, 2016$, from: http//www.mmu.ac.tz/uploads/article3.pdf

Carter, R. \& McCarthy, M.(1997). Exploring spoken English. Retrieved on February $1^{\text {st }}$, 2017 from : www.iises.net/download/Soubory/.../pp67-79_ijoteV2N3.pdf

Chaika, E.(2008). Language : The social mirror. Boston : Heinle Cengage Learning. Retrieved on January $6^{\text {th }}$, 2017 from www.ugr.es/.../14\%20\%20Nora\%20M\%20\%20Basurto.pdf

Corley , M d Linguistics Compass \& Stewart, O. W. (2008). Hesitation disfluencies in spontaneous speech : The meaning of um. Language and Linguistics Compass 2(4), p.589-604.

Clark, H.H\& Fox Tree, J. E. (2002). Using uh and um in spontaneous speaking, in cognition, 84: 73-111. Retrieved on January $6^{\text {th }}, 2017$ from : http://booksc.org/s/?q=clarck+and+fox+tree+2002+using+uh+and+um+in+spontane ous+bspeaking $\& \mathrm{t}=0$

Cresswell, J. W. (2014). Research design : Qualitative, quantitative, and mix methods approaches. London: Sage Publications Ltd.

Erten, S. (2013). Teaching fillers and students' usage : a study conducted at ESOGU preparation school. Retrieved on November $23^{\text {rd }}, 2016$ from https://www.google.co.id/webhp?sourceid=chromeinstant\&ion=1\&espv=2\&ie=UTF $8 \# q=J O R N A L+T E A C H I N G+F I L L E R S+A N D+S T U D E N T S+F I L L E R S+U S A G E$

Hatch, E., \& Lazaraton, A. (1991). The research manual: Design and statistics for applied linguistics. New York, NY: Newbury House Publishers.

Hatt, D. F..(1998). Maldemale language use in computer dyadic interactions. (MA Thesis). Launterian University Faculty of Graduate Studies.

Hellerman, J., \& Vergun, A.(2007).Language which is not taught : The discourse marker use of beginning adult learners of english. Journal of Pragmatics 39(1), 157-179.

Holmes, J. (2013). An introduction to sociolinguistics (learning about language). Retrieved on November $28^{\text {th }}$, 2016 from: http/l www.ugr.es/.../14\%20\%20Nora\%20M\%20\%20Basurto.pdf

Josephine., (2004). Fillers as seen on IRC. Unpublished Undergraduate Thesis, PetraChristian University, Surabaya. Retrieved on January $10^{\text {th }}, 2017$ from http://dewey.petra.ac.id/catalog/ft_detail.php?knokat=11426

Kurwanto, Hendra. (2011). Types and function of fillers used by the first semester students and the sevent semester students. Unpublished Undergraduated Thesis. Petra 
University Surabaya. Retrieved on December $25^{\text {th }}$, 2016 from : http//dewey.petra.ac.id/catalog/ft_detail.php?knokat=19468

Kridalaksana, H. (1993). Kamus linguistik. Jakarta: PT. Gramedia. Retrieved on January $10^{\text {th }}, 2017$ from : http://dewey.petra.ac.id/catalog/ftdetail.php? knokat=11426

Navratilova, L.(2015) Fillers used by male and female students of english education study program in argumentative talks. Retrieved on December $21^{\text {st }}, 2016$ from : http://ejournal.iainbengkulu.ac.id/index.php/linguists/article /view/121

Richards, Jack C., et al.( 1992). Dictionary of language teaching and applied linguistics. Retrieved on December $5^{\text {th }}$, 2016 from : http//shodhganga.inflibnet.ac.in/bitstream/.../12_chapter\%204.pdf

Rose, R., L. (1998). The communicative value of filled pauses in spontaneous speech. Retrieved on November 28 ${ }^{\text {th }}$, 2016, from : http://www.roselab. sci.waseda.ac.jp/resources/file/madissertation.pdf.

Santos, Alarcon \& Pablo. (2015). Fillers and the development of oral strategic competence in foreign language learning. Retrieved on December $21^{\text {st }}, 2016$ from : http://www.ugr.es/ portalin/articulos/PL_numero25/14\%20\%20Nora\%20M\%20\%2 0Basurto.pdf

Schiffrin.D. (1978). Discourse markers. Retrieved December 1, 2016 from : www.irjabs.com/files_site/paperlist/r_619_130201080356.pdf

Stenström, A. (1994). An introduction to spoken interaction. London: Longman. Retrieved on January $10, \quad 2017$ from : http://dewey.petra.ac.id/catalog/ft_detail.php?knokat=11426

Yule. (2006). The study of language. Cambridge : Cambridge University Press. 